\title{
Retraction
}

\section{Retracted: A Survey on Management Frameworks and Open Challenges in IoT}

\author{
Wireless Communications and Mobile Computing \\ Received 31 January 2019; Accepted 31 January 2019; Published 7 March 2019 \\ Copyright (c) 2019 Wireless Communications and Mobile Computing. This is an open access article distributed under the Creative \\ Commons Attribution License, which permits unrestricted use, distribution, and reproduction in any medium, provided the \\ original work is properly cited.
}

Wireless Communications and Mobile Computing has retracted the article titled "A Survey on Management Frameworks and Open Challenges in IoT" [1]. The article was found to not belong to the author, Dr. Farzad Kiani. Other researchers, Sufian Hameed and Faraz Idris, say the research is theirs and was published without their knowledge or permission.

Dr. Kiani said he had received the article in good faith from a now-deceased colleague, he did not intend to violate anyone's rights, he sincerely apologizes to the researchers, and he agreed to retraction.

\section{References}

[1] F. Kiani, "A survey on management frameworks and open challenges in IoT," Wireless Communications and Mobile Computing, vol. 2018, Article ID 9857026, 33 pages, 2018. 